\title{
Integrative taxonomy reveals a new species of Callisto (Lepidoptera, Gracillariidae) in the Alps
}

\author{
Natalia Kirichenko ${ }^{1,2,3}$, Peter Huemer ${ }^{4}$, Helmut Deutsch ${ }^{5}$, Paolo Triberti ${ }^{6}$, \\ Rodolphe Rougerie ${ }^{1,7}$, Carlos Lopez-Vaamonde'
}

I INRA, UR0633 Zoologie Forestière, F-45075 Orléans, France 2 Sukachev Institute of Forest SB RAS, Akademgorodok 50/28, 660036, Krasnoyarsk, Russia 3 Siberian Federal University, 79 Svobodny pr., 660041, Krasnoyark, Russia 4 Naturwissenschaftliche Abteilung, Tiroler Landesmuseen Betriebsgesellschaft m.b.H., Feldstr. 11a, A-6020 Innsbruck, Austria 5 Bannberg 22, 9911 Assling, East Tyrol, Austria 6 Museo Civico di Storia Naturale, Lungadige Porta Vittoria 9, I37129, Verona, Italy 7 Museum National d'Histoire Naturelle, UMR7205 ISYEB, F-75005 Paris, France

Corresponding author: Natalia Kirichenko (nkirichenko@yahoo.com)

Academiceditor: E. vanNieukerken |Received3September2014|Accepted 11December2014|Published20January 2015

http://zoobank.org/3AB87E84-E2DE-4B1A-B9C9-58E553FA37C5

Citation: Kirichenko N, Huemer P, Deutsch H, Triberti P, Rougerie R, Lopez-Vaamonde C (2015) Integrative taxonomy reveals a new species of Callisto (Lepidoptera, Gracillariidae) in the Alps. ZooKeys 473: 157-176. doi: 10.3897/ zookeys.473.8543

\begin{abstract}
Europe has one of the best-known Lepidopteran faunas in the world, yet many species are still being discovered, especially in groups of small moths. Here we describe a new gracillariid species from the southeastern Alps, Callisto basistrigella Huemer, Deutsch \& Triberti, sp. n. It shows differences from its sister species $C$. coffeella in morphology, the barcode region of the cytochrome $c$ oxidase I gene and the nuclear gene histone H3. Both C. basistrigella and C. coffeella can co-occur in sympatry without evidence of admixture. Two C. basistrigella specimens show evidence of introgression. We highlight the importance of an integrative approach to delimit species, combining morphological and ecological data with mitochondrial and nuclear sequence data. Furthermore, in connection with this study, Ornix blandella Müller-Rutz, 1920 , syn. n. is synonymized with C. coffeella (Zetterstedt, 1839).
\end{abstract}

\section{Keywords}

COI, DNA barcoding, histone $\mathrm{H} 3$, mitochondrial-nuclear discordance, leaf-mining moths, contact zone, new species

Copyright Natalia Kirichenko et al. This is an open access article distributed under the terms of the Creative Commons Attribution License (CC BY 4.0), which permits unrestricted use, distribution, and reproduction in any medium, provided the original author and source are credited. 


\section{Introduction}

Lepidoptera - butterflies and moths - are one of the most well-documented insect orders, but it is estimated that thousands of species, especially small-sized ones inhabiting the tropics, are still awaiting formal description. The integration of genetic data into taxonomic studies, especially with the advance of DNA barcoding campaigns (the construction of libraries of DNA barcodes for identification), has revealed many cases of cryptic or overlooked species in the tropics (Janzen et al. 2009, 2012), but also in some of the most studied regions such as Europe (Mutanen et al. 2012a, b, c, 2013).

Leaf-mining micro-moths in the family Gracillariidae are no exception. A study based on the analysis of DNA barcodes recently revealed a considerable number of undescribed species in the Neotropical region (Lees et al. 2013). In Europe, the systematics of this family is relatively well known, with 23 genera and 260 species recorded (De Prins and De Prins 2014) with new species still being discovered and described (Laštůvka and Laštůvka 2006, 2012; Triberti 2007; Laštůvka et al. 2013).

Here we focus on the gracillariid Callisto coffeella (Zetterstedt, 1839), an arcticalpine species, which has been recorded from northern Europe, the Alps and a few other mountain areas of Europe. Its larvae initially mine leaves of several species of Salix and later feed in a folded leaf (Bengtsson and Johansson 2011). As all known Callisto species, $C$. coffeella adults have forewings with dark brown to blackish ground color with silvery white, oblique streaks (Figs 1-4). Due to these conspicuous wing markings they are relatively easy to identify. The alpha taxonomy of European Callisto has been established for a long time, with Callisto insperatella (Nickerl, 1864) being the most recently described species.

In a recent DNA barcoding study, Huemer (2011) found two genetic lineages within $C$. coffeella: one lineage formed by Austrian individuals from northern and central Alps, and a second one consisting of Italian specimens from the Southern Alps. Members of these two lineages differ on the basal silvery line of the forewings, which is transverse in south-eastern Alpine populations but vertical in all other examined populations (Fennoscandia, Northern and Central Alps). However, the author in contrast to other morphologically well-defined congeners found no differences in male and female genitalia. On the basis of phenotypical and genetic differences, it was suggested by P. Huemer that the south-eastern Alpine populations might represent a different subspecies.

Here we present new genetic, distribution and morphological data that support the hypothesis that individuals of $C$. coffeella from the south-eastern Alps represent a distinct lineage that we formally describe as a new species - Callisto basistrigella Huemer, Deutsch \& Triberti, sp. n. 


\section{Materials and methods}

\section{Collections}

Specimens examined in this study were obtained by rearing adults from leaf mines and by collecting adults flying by day around Salix bushes, mainly S. glabra Scop., 1772 and S. waldsteiniana Willd., 1806, but also a few S. appendiculata Villars, 1789 and S. hastata L., 1753. Some adults were collected at light trap or flew in the early morning hours. Data for all specimens studied morphologically and genetically can be found in the Suppl. material 1: Table S1.

\section{Morphology}

We examined the morphology of 135 dried, pinned and mostly set specimens belonging to C. coffeella s.l., the majority originating from the Alps, and half a dozen from Scandinavia. Pinned specimens were photographed with an Olympus E 3 digital camera and an Olympus SZX 10 binocular microscope, and processed with Helicon Focus 4.3 software, resulting in multiple images. Images were later edited by using Adobe Photoshop Lightroom 2.3 software. Genitalia were photographed with an Olympus E1 digital camera through an Olympus $\mathrm{BH} 2$ microscope.

Genitalia dissections and slide mounts followed Robinson (1976). Morphometric analysis was carried out on genital preparations of 16 adult males (5 from the southeastern alpine populations and 11 from Northern and Central alpine populations). Seven parameters were measured: phallus, valva, saccus, anellus and anellus process lengths, valva width and valva constriction.

All measurements were done on a Leica M 165C stereomicroscope by P. Triberti and expressed in $\mathrm{mm}$. The dataset resulting from these measurements was analyzed using a multivariate approach - one-way ANOVA (Montgomery 2001), with species as a single categorical independent variable and the seven dependent measurement length variables mentioned above. Significance of each genital parameter was analyzed using a non-parametric Mann-Whitney test (MWT). Since our sampling size was rather small, particularly for southern populations, MWT was used because it does not require the normality of the data and allows tied values (Hollander and Wolfe 1999). With MWT, we tested the null hypothesis of no morphological differences. To avoid inter-correlations between dependent variables, we first estimated residual values of the correlated parameters using similar linear transformations (Draper and Smith 1998). We used this procedure for valva, saccus, and anellus process lengths, which were strongly correlated with phallus length. We used STATISTICA 8.0 (Stat Soft. Inc., USA) to conduct the analyses. 


\section{DNA sequence analysis}

DNA extracts were prepared from a single hind leg removed from each of 21 specimens of $C$. coffeella s.l. DNA extraction, PCR amplification and sequencing of the barcode region were carried out at the Canadian Centre for DNA Barcoding (CCDB, Biodiversity Institute of Ontario, University of Guelph) following standard protocols (De Waard et al. 2008). In addition, 14 samples were processed at INRA (Orléans, France). DNA was extracted using QIAGEN DNeasy Blood \& Tissue Kit according to the manufacturer's protocol. The COI barcoding fragment, $658 \mathrm{bp}$, was amplified via PCR using the primers LCO (5' GGT CAA CAA ATC ATA AAG ATA TTG G 3') and HCO (5' TAA ACT TCA GGG TGA CCA AAA AAT CA 3') and following standard conditions for the reaction (Folmer et al. 1994). PCR products were purified using the QIAGENAquick PCR purification kit and after used for the cycle sequencing reaction with Big Dye 3.1 ( 25 cycles of $35 \mathrm{~min}$ at $94^{\circ} \mathrm{C}, 30 \mathrm{~min}$ at $46^{\circ} \mathrm{C}$ and $1 \mathrm{~min} 30 \mathrm{sec}$ at $72^{\circ} \mathrm{C}$ ).

Furthermore, 21 samples with DNA barcodes were also sequenced for the nuclear gene histone $\mathrm{H} 3$, a $-350 \mathrm{bp}$ fragment, at INRA, Orléans. PCR for this gene was performed using primers Hex AF (5' -ATG GCT CGT ACC AAG CAG ACG GC -3') and Hex AR (5' -ATA TCC TTG GGC ATG ATG GTG AC-3') (Svenson and Whiting 2004) for 40 cycles $\left(1 \mathrm{~min}\right.$ at $94^{\circ} \mathrm{C}, 1 \mathrm{~min}$ at $45^{\circ} \mathrm{C}, 1 \mathrm{~min}$ at $65^{\circ} \mathrm{C}$ and $10 \mathrm{~min}$ at $65^{\circ} \mathrm{C}$ ). Sequencing was carried out using a $3100 \mathrm{ABI}$ genetic analyzer (Hitachi) with Big Dye 3.1 ( 25 cycles of $10 \mathrm{~min}$ at $96^{\circ} \mathrm{C}, 5 \mathrm{~min}$ at $50^{\circ} \mathrm{C}, 4 \mathrm{~min}$ at $60^{\circ} \mathrm{C}$ ). Both COI and histone $\mathrm{H} 3$ sequences were aligned using CodonCode Aligner 3.7.1. (CodonCode Corporation).

Sequence divergences were quantified using the Kimura 2-parameter model implemented within the analytical tools on BOLD (www.boldsystems.org) (Ratnasingham and Hebert 2007). A neighbor-joining (NJ) tree was constructed with MEGA 5.05 (Tamura et al. 2011). As a reference and to visually root the tree, we used one specimen of Callisto insperatella (Nickerl, 1864) (GRPAL094-10) for the COI tree and one specimen of Parornix betulae (Stainton, 1854) (GRACI621-10) for the histone H3 tree.

\section{Specimen and sequence information}

Details on the collecting data for each specimen, as well as a photograph of vouchers, sequence records, trace files, and primer sequences used for PCR amplification, together with GenBank accession numbers are available through the following dataset (http://dx.doi.org/10.5883/DS-CALLISTO) in BOLD (www.boldsystems.org).

\section{Specimen depositories}

LMK Landesmuseum Kärnten; Klagenfurt, Austria.

MCSN Museo Civico di Storia Naturale, Verona, Italy.

MCSNB Museo Civico di Scienze Naturali “E. Caffi”, Bergamo, Italy. 
SMNK Staatliches Museum für Naturkunde, Karlsruhe, Germany.

TLMF Tiroler Landesmuseum Ferdinandeum, Innsbruck, Austria.

UO University of Oulu, Finland.

VND inatura Erlebnis Naturschau Dornbirn, Austria.

ZSM Zoologische Staatssammlung, Munich, Germany.

\section{Private collections}

PCHD Helmut Deutsch, Bannberg, Assling, Tyrol, Austria.

PCJR Jurij Rekelj, Kranj, Slovenia.

PCJS Jürg Schmid, Illanz, Switzerland.

PCJW Josef Wimmer, Steyr, Austria.

PCJWdP Jurate and Willy De Prins, London, UK.

PCSG Stanislav Gomboc, Slovenia.

\section{Results}

\section{Morphology}

Morphological analysis of the 135 specimens confirms the differences observed in wing pattern in the south-eastern alpine population. Eighty-two of these individuals were diagnosed as Callisto coffeella and 53 as the new species $C$. basistrigella. In addition, we detected two moths which morphologically corresponded to $C$. basistrigella but with a COI barcode they fell into the cluster of $C$. coffeella (see below Molecular divergences).

\section{Callisto coffeella (Zetterstedt, 1839)}

Oecophora coffeella Zetterstedt 1839: 1009.

Oecophora interruptella Zetterstedt 1839: 1009 [synonymised by Benander 1940: 61]. Ornix caelatella Zeller 1847: 585-586 [synonymised with Oecophora interruptella Zetterstedt, 1839 by Wocke (1862: 243)].

Ornix blandella Müller-Rutz 1920: 343. syn. n.

Annickia alpicola Gibeaux 1990: 23. [synonymised by Huemer 1990: 133].

Remarks. Oecophora coffeella was described from an unspecified number of male specimens collected on the $14^{\text {th }}$ of July near Bjerkvik [according to original description 'Bjoerkvik" in Norwegian Lappland] (Zetterstedt 1839). Oecophora interruptella was described on the same page from a single male collected in 1836 in the Swedish province Dalarna, i.e. Dalecarlia by Boheman and from a female collected on $22^{\text {nd }}$ of July 1812 near Gibostad, i.e. Giebostad, Norway. The type material was examined and figured by Benander (1940) who synonymized both taxa. 

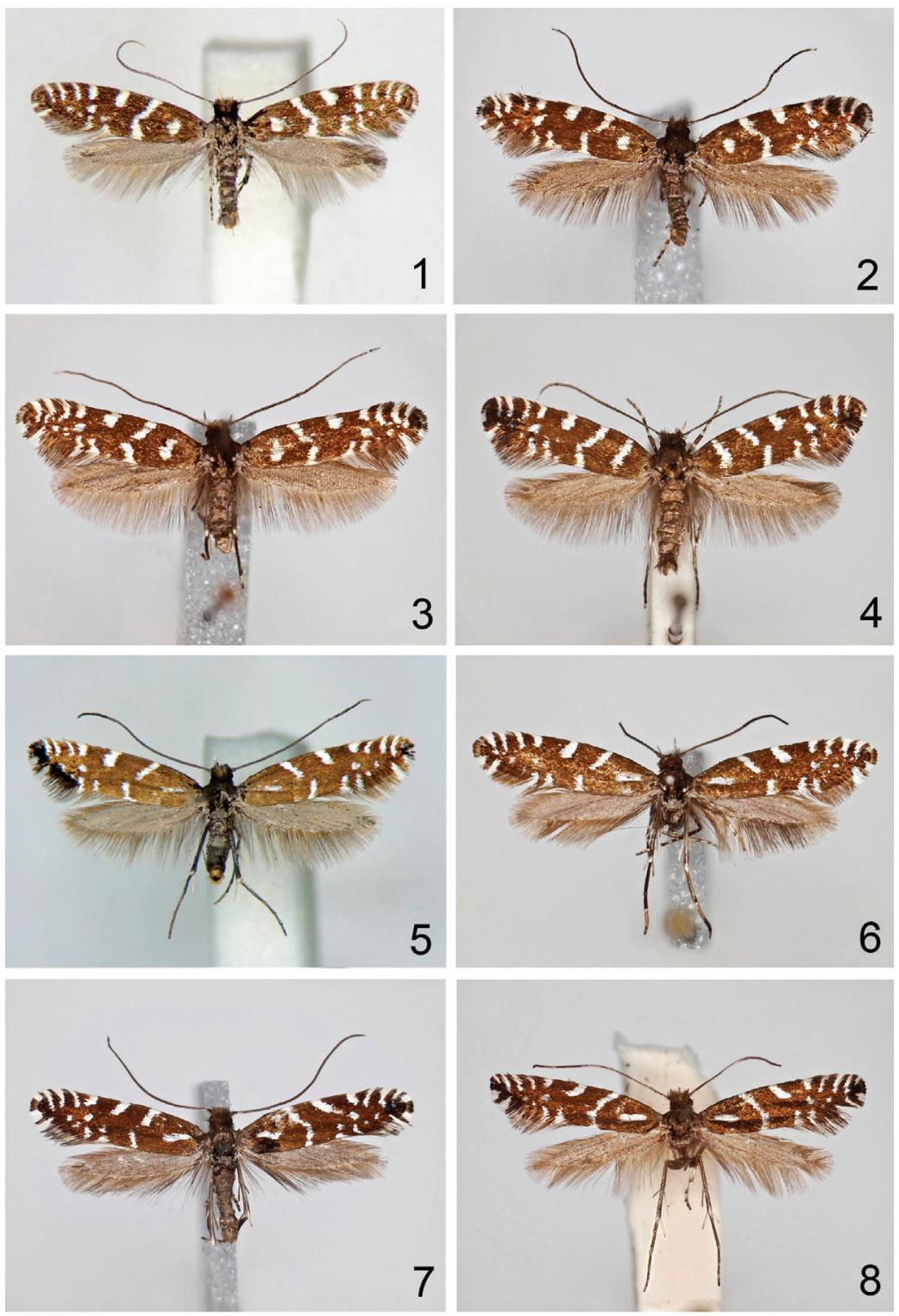

Figures I-8. Callisto adults in dorsal view. I C. coffeella, male, Austria, Leitnertal, Oberer Stuckensee, 2150 m, 07.IX.2013, leg. Deutsch (PCHD) | voucher specimen № 3 | sample ID - NK318 | process ID CALCO003-14 2 C. coffeella, male, Austria, Nordtirol, Bodenalpe, 2000 m, 9.-10.VII.1984, leg. Burmann (TLMF); 3 C. coffeella, male, Austria, Vorarlberg, Brandnertal, Böser Tritt, 1700-1800 m, 04.VII.1983, leg. Huemer (TLMF) 4 C. coffeella, female, Austria, Nordtirol, Obergurgl, 2000 m, e.l. M.III.1970, leg. Burmann (TLMF) 5 C. basistrigella sp. n., male, East Tyrol, Lienzer Dolomiten, Laserz, Dolomitenhütte, 1600 m, 12.VII.2013, leg. Deutsch (TLMF) | voucher specimen № $10 \mid$ sample ID NK325 | process ID CALCO010-14 6 C. basistrigella sp. n., male, Italy, Prov. Udine, Mte. Sernio, Forcella Nuviernulis, 1700 m, 16.VII.1988, leg. Huemer (TLMF) 7 C. basistrigella sp. n., male, Italy, Prov. Udine, Mt. Canin N, Rif. Gilberti, 1850-1950 m, 29.VII.2001, leg. Huemer (TLMF) 8 C. basistrigella sp. n., female, Italy, Prov. Udine, Montasio, 16.IX.1951, leg. Pinker (TLMF). 
Annickia alpicola was described from a single male specimen collected in the French Alps (Gibeaux 1990) and later synonymized with Callisto coffeella by Huemer (1990).

Ornix caelatella was described from a single male collected in Montenero (Tuscany, Italy) in May by Josef Mann (Zeller 1847), later this species was synonymized with Ornix interruptella (= Callisto coffeella) by Wocke (1862). The whereabouts of the holotype is unknown but the detailed original description and the Mediterranean locality disagree with both $C$. coffeella and $C$. basistrigella. However, a further specimen from Styria (Austria), later determined by Zeller (1850) as caelatella but defined as a particular form, may be conspecific with $C$. coffeella. We conclude that Ornix caelatella is a dubious taxon until the holotype will be rediscovered.

Ornix blandella was described by Müller-Rutz (1920) from a specimen bred by Paul Weber in Parpan (Switzerland) at 1500 m on Salix sp. Despite a focused search carried out by one of the authors (P. Triberti), the types were not found. However it was possible to study the original Müller-Rutz watercolours preserved in Naturhistorisches Museum Basel (Nr. 159 and 522) and they fully agree with typical C. coffeella. On the basis of what we conclude that Ornix blandella Müller-Rutz is a new synonym of $C$. coffeella Zetterstedt.

Description. Adult (Figs 1-4). Head dark brown, with distinct dark brown tuft of raised scales on vertex, frons lighter, greyish brown, labial palp cream. Wingspan 10-12 $\mathrm{mm}$; forewing dark brown with distinct whitish silvery markings: transverse oblique sub-basal line showing sexual dimorphism, well developed from costa to fold in female (Fig. 4), shorter in male (Figs 1-3) and not extending to costa, rarely reduced to a spot in fold; angulate fascia at one third frequently separated into costal and tornal line; costa furthermore with short median strigula and two pairs of distal strigulae; dorsum with two small distal spots; small discal spot, supplemented by up to 2-3 spots distally; particularly distomedial spots silvery rather than whitish silvery; fringes with distinct cilia line, basal half darker than distal half, termen with two whitish spots; hindwing grey-brown with same-colour fringes.

Genitalia and eighth segment male (Figs 9-10, 13-14). Sternite 8 projected, bilobed. Tuba analis with long and thin subscaphium; valva slender, distally widened, with evenly rounded apex; vinculum laterally projected; saccus long and slender, rodlike, about as long as valva; anellus with pair of long and projecting processes; phallus slender, straight, about twice as long as valva, without distinct modifications, apically pointed.

Genitalia female (Fig. 17). Apophyses posteriors shorter than anteriores; segment 8 short, bare, intersegmental membrane to papillae anales very reduced; sterigma simple with ostium bursae wide, ventral margin medially more or less indented; antrum cupshaped; ductus bursae moderately long and smooth, short sclerite just before antrum; corpus bursae, oval, longer than ductus bursae, signa formed by scobinations arranged in two longitudinal bands.

Distribution. The species is restricted to higher mountain areas and shows an arctic-alpine distribution pattern. According to various publications (i.e. Bengtsson and Johansson 2011, Heath and Emmet 1985, Huemer and Tarmann 1993, SwissLep- 

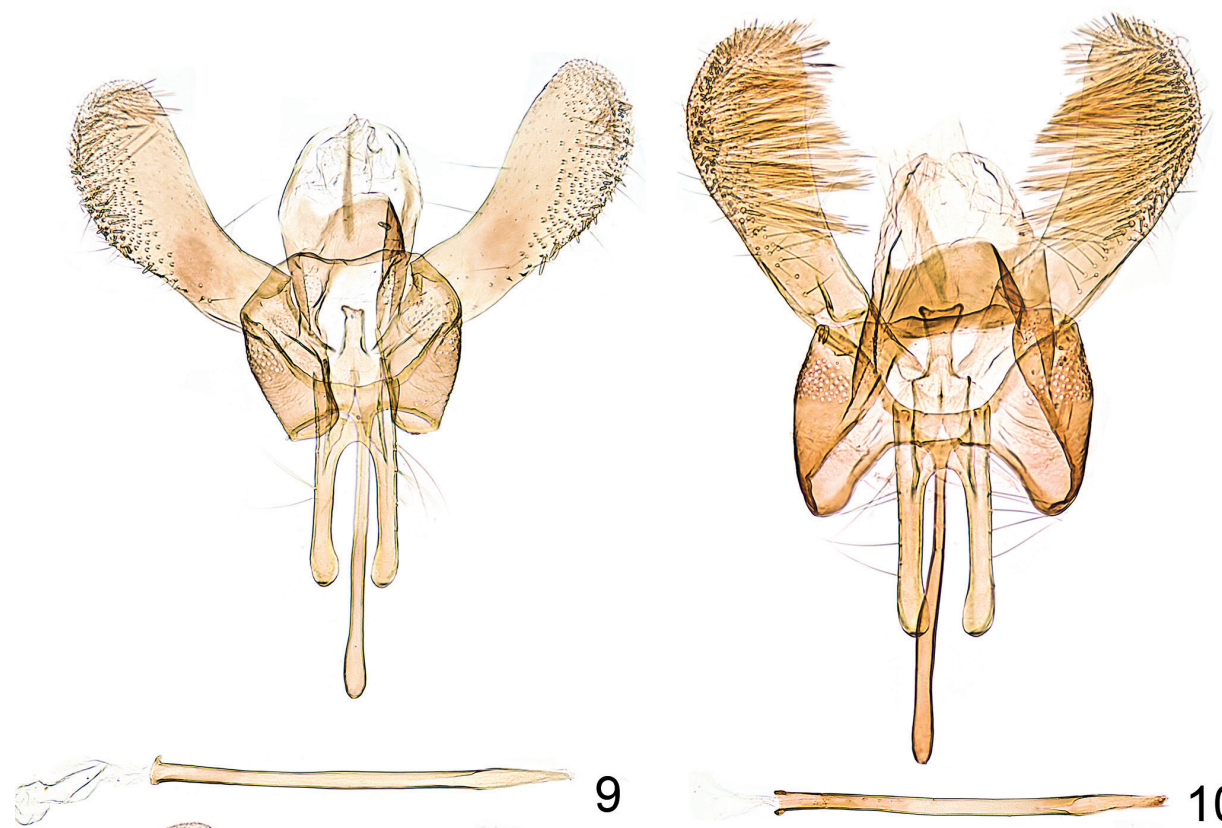

9

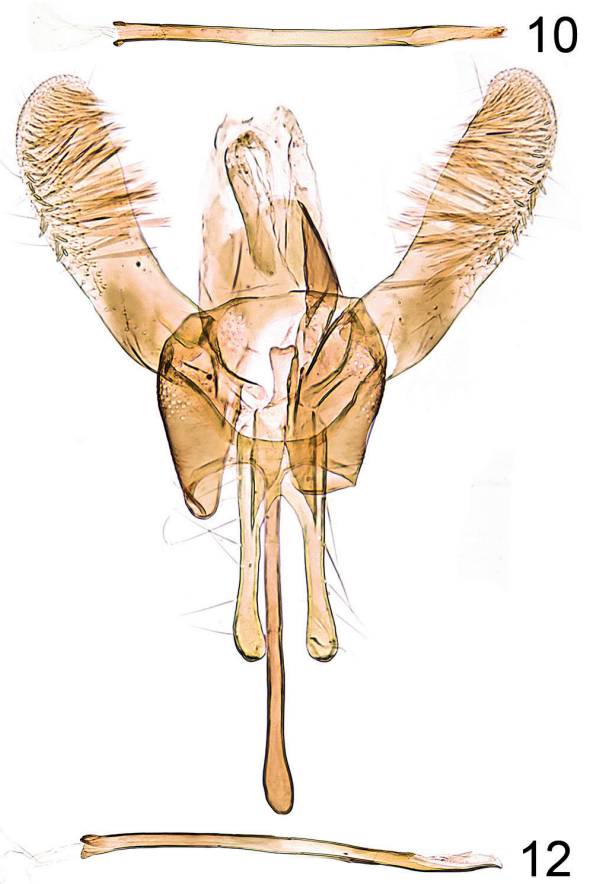

Figures 9-12. Callisto, male genitalia. 9 C. coffeella, Vorarlberg Zürs, 1800 m, 29.VI.1939, leg. Burmann, gen. slide TIN 1 (TLMF) 10 C. coffeella Teriol sept., Vent 2000 m, e.l. 01.III.1956, leg. Burmann, gen. slide TIN 4 (TLMF) I I C. basistrigella sp. n., Italia sept. Prov. Udine, Mte. Sernio, Forcella Nuviernulis 1700 m, 16.VII.1988 leg. Huemer gen. slide TIN 2 (TLMF) I 2 C. basistrigella sp. n. Italia sept. Prov. Udine, Mte. Sernio, Forcella Nuviernulis 1700 m, 16.VII.1988 leg. Huemer gen. slide TIN 3(TLMF). 
Team 2010) the species is locally distributed in the central and northern parts of Scandinavia, northern Scotland, and in the eastern, northern and central Alps. Most of these regions were included in our study, particularly alpine regions of Italy, Austria, Switzerland and Slovenia; sampling was also done in southeast of Germany and in Scandinavia (Norway, Sweden, Finland). In the Southern Alps it is known from a single record in France and from Aosta Valley to Carnic Alps in Italy. Callisto coffeella is also reported from Western Russia (Sinev 2008), Ukraine, Poland, Slovakia, and United Kingdom (De Prins and De Prins 2014) but we have been unable to check material from these countries.

Bionomics. The larval stage feeds on various species of mountainous Salix such as Salix arbuscula L., 1753 (which may refer to S. arbuscula in northern Europe or $S$. waldsteiniana in Central Europe), S. phylicifolia L., 1753 (Heath and Emmet 1985), S. repens L., 1753 (syn: S. fusca), S. myrsinifolia Salisb., 1796, S. silesiaca Willd., (1806) [basionym] (De Prins and De Prins 2014). In our study, C. coffeella was also reared from Salix glabra. Initially the larva produces a short epidermal gallery which suddenly widens to a blotch tentiform mine on the lower surface of a leaf, similar in appearance to mines of the genus Phyllonorycter. Later the mine is vacated and the larva forms a shelter along a leaf margin, folding an edge downwards as in many Parornix. Pupation takes place in a cocoon on the branch of the host-plant or in the laboratory between leaf litter and tissue. Hibernation occurs in the pupal stage. The adult is on the wing in June and July. It can be found during the day, most frequently in the morning and early evening flying around the hostplant. The species lives in montane and subalpine habitats of the dwarf-shrub zone both on calcareous and siliceous soil.

\section{Callisto basistrigella Huemer, Deutsch \& Triberti, sp. n.} http://zoobank.org/95B2011C-A39A-436E-8FF4-35ABEE5827E1

Type material. Holotype (Fig. 5): 1 male, East Tyrol, Lienzer Dolomiten, Laserz, Dolomitenhütte, 1600 m, 12.VII.2013, leg. Deutsch (TLMF) | voucher specimen № 10 | sample ID - NK325 | process ID CALCO010-14.

Paratypes. 33 males and 11 females.

Austria: 3 males, East Tyrol, Lienzer Dolomiten, Lavanter Almtal, 1200-1400 m, 07.VI.1998, leg. Deutsch (TLMF); 1 male, East Tyrol, Lienzer Dolomiten, Laserzgebiet, 1800-2000 m, 21.VI.1999, leg. Deutsch (TLMF); 1 male, East Tyrol, Carnic Alps, Leitnertal, Oberer Stuckensee, 2150 m, 14.VII.2013, leg. Deutsch (PCHD) | voucher specimen № $8 \mid$ sample ID - NK323 | process ID CALCO008-14; 2 males, East Tyrol, Carnic Alps, Leitnertal, Oberer Stuckensee, 2150 m, 07.IX.2013, leg. Deutsch (PCHD) | voucher specimens № 1 and № 2 | sample IDs - NK316 and NK317 | process Ids CALCO001-14 and CALCO002-14; 1 female, East Tyrol, Lienzer Dolomiten, Hochstadel, 2000 m, VII.1952, leg. Pinker (TLMF); 2 females, East Tyrol, Carnic Alps, Leitnertal, Oberer Stuckensee, 2150 m, 07.IX.2013, leg. Deutsch 

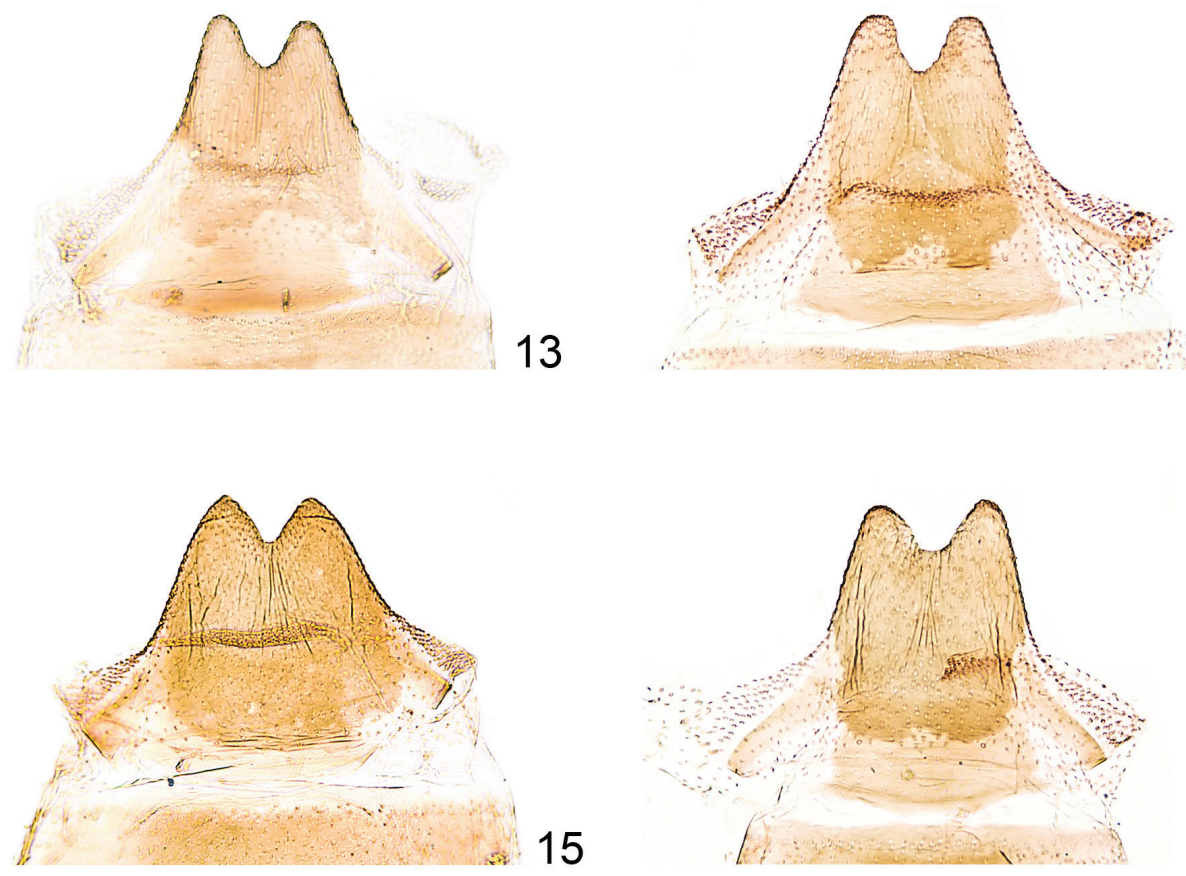

\section{6}

Figures 13-16. Callisto, male, segment 8. I3 C. coffeella, Vorarlberg Zürs, 1800 m, 29.VI.1939, leg. Burmann, gen. slide TIN 1 (TLMF) I 4 C. coffeella, Teriol sept., Vent 2000 m, e.l. 01.III.1956, leg. Burmann, gen. slide TIN 4 (TLMF) I5 C. basistrigella sp. n., Italia sept. Prov. Udine, Mte. Sernio, Forcella Nuviernulis 1700 m, 16.VII.1988, leg. Huemer, gen. slide TIN 2 (TLMF) I 6 C. basistrigella sp. n., Italia sept. Prov. Udine, Mte. Sernio, Forcella Nuviernulis 1700 m, 16.VII.1988 leg. Huemer gen. slide TIN 3 (TLMF).

(PCHD) | voucher specimens № 4 and № 6 sample | sample IDs - NK319 and NK321 | process Ids CALCO004-14 and CALCO006-14.

Italy: 4 males, Prov. Belluno, Passo di Valparola E, 2200-2300 m, 20.VII.2009, leg. Huemer (TLMF); 1 female, same data but gen. slide TRB3893 and BC TLMF Lep 01801 (TLMF); 1 male, A. Carniche, Sappada, Casera Sesis, 1800 m, 12.VI. unknown year, leg. Rocca, gen. slide TRB 1778 (MCSN); 1 male, A. Carniche, Sappada, Passo Siera, 1600 m, 04.VII.1933, leg. Rocca, gen. slide TRB 1785 (MCSN); 1 male, A. Carniche, Sappada, Hosthaus, 1800 m, 14.VII.1936, leg. Rocca (MCSN); 2 males, 2 females, A. Carniche, Sappada, L. d'Olbe, 2000 m, 02.VII.1933, leg. Rocca, gen. slide TRB284 male, TRB3894 male (MCSN); 1 male, Prov. Udine, Mte. SernioMassiv Forcella Nuviernulis 1700 m, 16.VII.1988, leg. Huemer, GU TIN2 male P. Huemer 'Callisto coffeella Zett. det. Triberti' (TLMF); 1 male, Prov. Udine, Mte. Sernio-Massiv Forcella Nuviernulis 1700 m, 16.VII.1988, leg. Huemer, GU TIN3 male (TLMF); 1 male, 1 female, Prov. Udine, Montasio, 16.IX.1951, leg. Pinker, gen. slide TIN8 female (TLMF); 11 males, 1 female, Prov. Udine, Monte Canin N, Rif. Gilberti Umg., 1850-1950 m, 29.VII.2001, leg. Huemer (TLMF); 1 male, 1 fe- 
male, Prov. Udine, Monte Canin, Biv. Marussich, 2040 m, 06.VII.2002, leg. Wieser (LMK); 3 males, Prov. Udine, Monte Canin, Sella di Grubia, 1700 m, 20.VI.2003, leg. Wieser (LMK).

Slovenia: 1 female, Crna Prst, 1400 m, 18.VII.1899, leg. Penther (TLMF).

Diagnosis. In external appearance $C$. basistrigella is distinguishable from $C$. coffeella by its forewing pattern. In $C$. basistrigella, the sub-basal whitish silvery line of the forewing is almost parallel and lies in the fold, whereas in C. coffeella this line is transverse to the wing axis or reduced to a spot. On average, the forewings are slightly narrower than in $C$. coffeella (visible in series). Sexual dimorphism, as observed in $C$. coffeella, is absent in $C$. basistrigella. Genitalia do not provide obvious diagnostic differences but the length of the phallus is significantly longer in C. basistrigella than in C. coffeella although more specimens would be needed to confirm this difference (see Genital morphometrics).

Description. Adult (Figs 5-8). Wingspan 10.5-13.0 mm; forewing in sub-basal area with longitudinal, slightly oblique, whitish silvery line in fold. Other characters as described above for $C$. coffeella. The angulate fascia at one third of forewing frequently separated into costal and tornal line.

Genitalia and subgenital segments male (Figs 11-12, 15-16). As described above for C. coffeella.

Genitalia female (Fig. 18). As described above for C. coffeella.

Distribution. Only known from a small area in the south-eastern Alps, ranging from the Dolomites (Italy) in the west to the Julian Alps (Slovenia) in the east and the Carnic Alps and Lienzer Dolomiten (Austria) in the north (Fig. 19A, B).

Etymology. The name refers to the characteristic wing markings.

Bionomics. Early stages are undescribed. Both C. basistrigella and C. coffeella adults have been collected during the day, flying around low bushes of alpine Salix glabra and S. waldsteiniana. The flight period is largely dependent on exposure and snow coverage and usually extends between early June and late July. Under extreme conditions such as harsh winters adults have been collected as late as mid-September. The habitats are related to the dwarf-shrub zone and include subalpine meadows, rock formations and scree with Salix-bushes and shrubs. C. basistrigella is restricted to limestone with an altitudinal range from about 1200 to $2300 \mathrm{~m}$.

Genital morphometrics. Multivariate ANOVA analysis based on morphometric of seven genital characteristics of the male moths failed to find any significant difference between $C$. coffeella and $C$. basistrigella (Wilks' $\lambda=0.36, F=2.07, p=0.16$ ). Six out of seven parameters, i.e valva, saccus, anellus and anellus process lengths, valva width and valva constriction were not found to differ in the two species. Non-parametric MannWhitney test however indicated that the phallus is significantly longer in Callisto basistrigella than in C. coffeella (MWT : $Z=2.36, N=16, p=0.02$ ), although sample sizes remain relatively small (C. basistrigella $\mathrm{N}=5$, C. coffeella $\mathrm{N}=11$ ) (Fig. 20). Two specimens of $C$. basistrigella from Sappada (Italy) made significant contributions to phallus length value of the species, exceeding the averaged length of $C$. coffeella phallus by $27 \%$. 

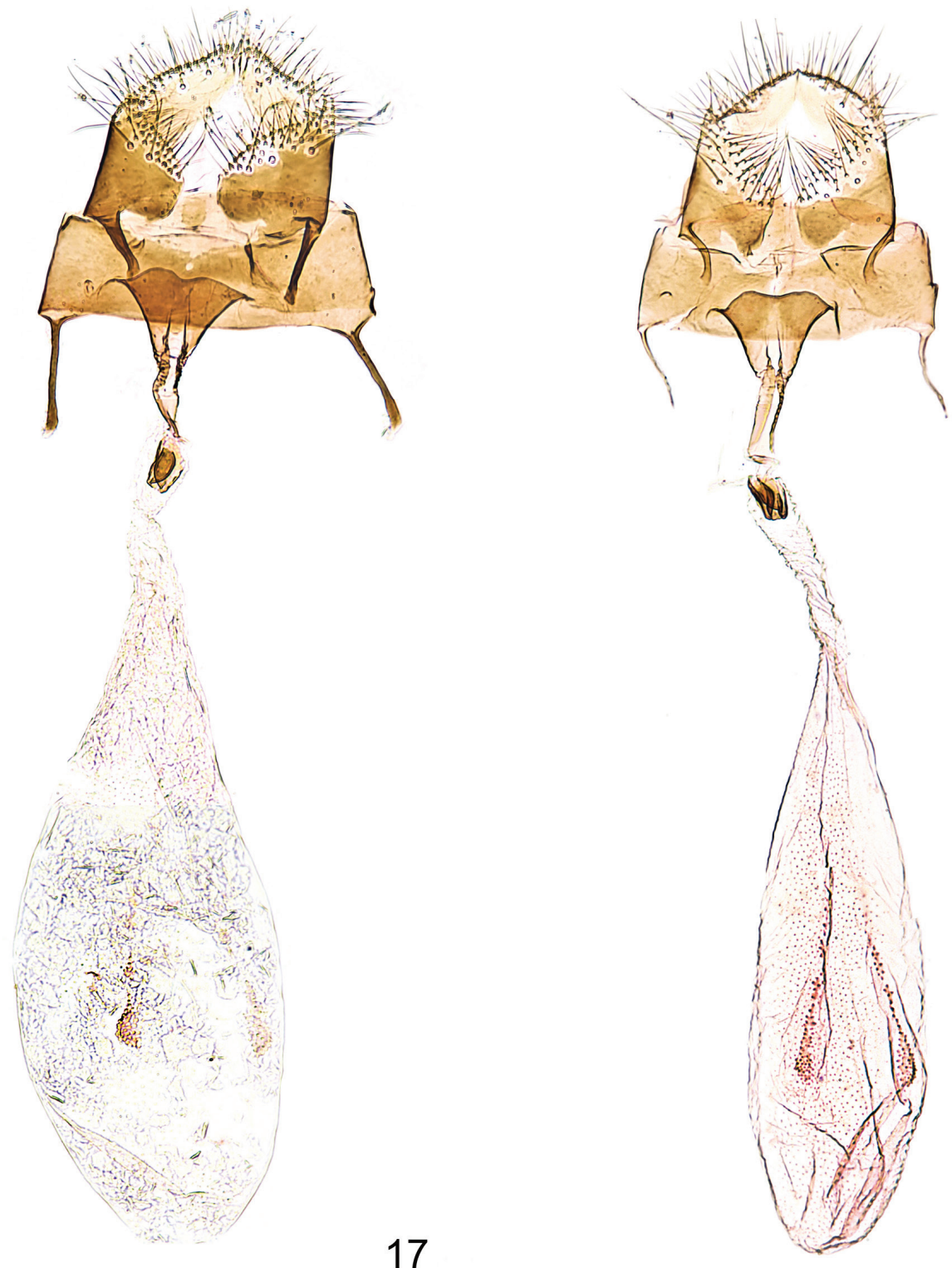

Figures 17-18. Callisto, female genitalia. 17 C. coffeella, Austria, Vorarlberg, Brandnertal, Böser Tritt, 1700-1800 m, 02.VII.1983, leg. Huemer gen. slide TIN 9 (TLMF) 18 C. basistrigella sp. n., Prov. Udine, Montasio, 16.IX.1951, leg. Pinker gen. slide TIN 8 (TLMF).

\section{Molecular divergences}

DNA barcodes. We obtained DNA barcodes for 21 specimens of $C$. coffeella and 14 specimens of $C$. basistrigella. Their analysis revealed that the samples of these species form two distinct clusters in the NJ tree (Fig. 21A), with two exceptions: one Slovenian 

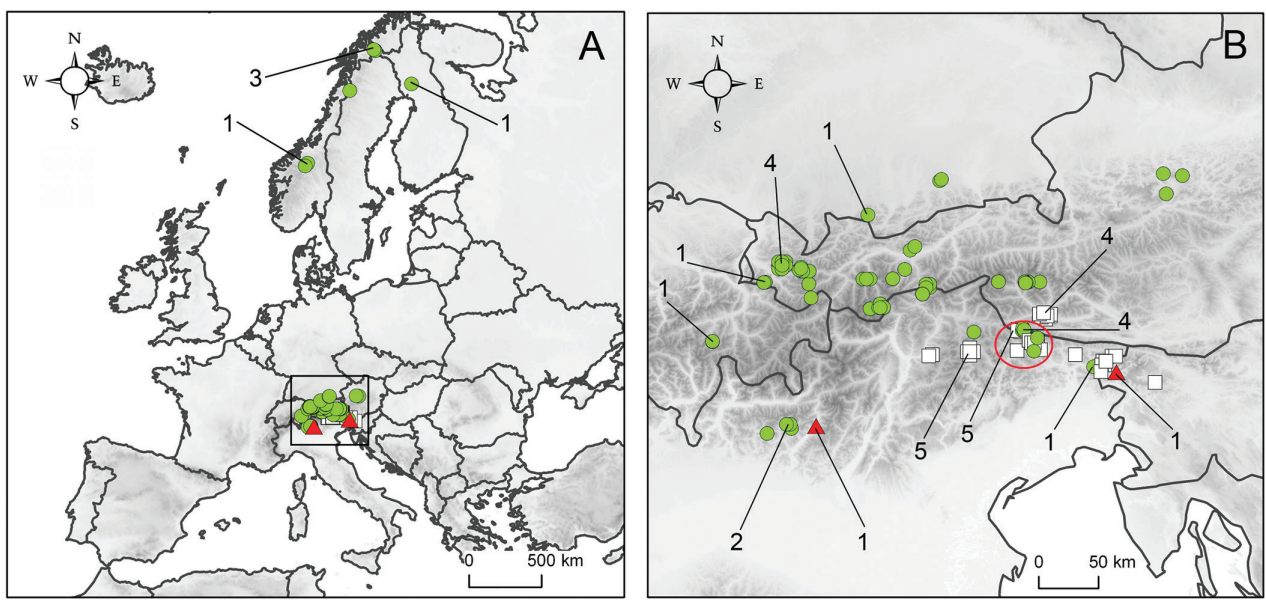

Figure 19. A sampling area of Callisto coffeella and C. basistrigella in Europe. B close up of the distribution of C. coffeella (green circles) and C. basistrigella (white squares) in the Alps; two C. basistrigella specimens (red triangles) show evidence of introgression. On Figs 19A, 19B, the 35 barcoded specimens are shown with numbers (1-5). The red circle on Fig. 19B shows the contact zone where both species occur together (Leitnertal, Eastern Tyrol, Austria and Sappada, Italy). When several samples were investigated per locality, the samples with the same coordinates have been slightly shifted in order to visualize overlapping data points on Fig. 19B.

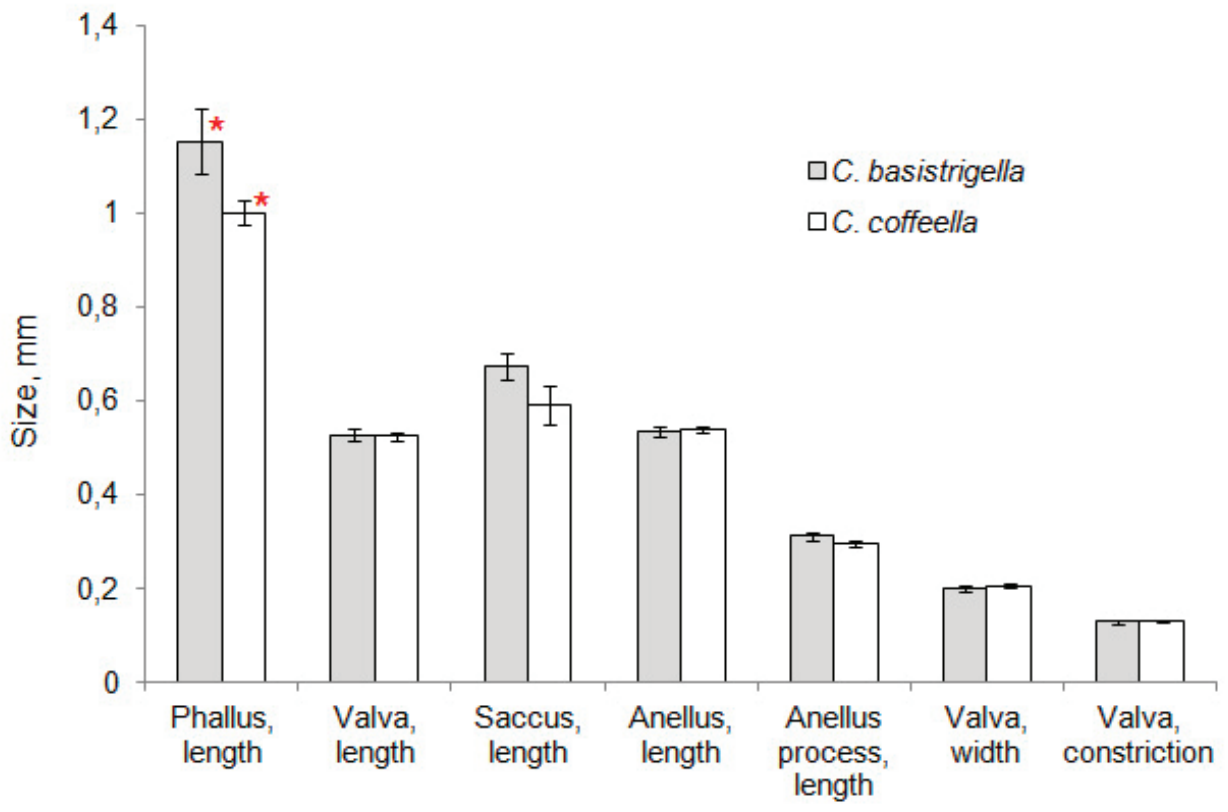

\section{Genital characters}

Figure 20. Genitalia measurements (mean values \pm standard error) for the two Callisto species studied. The bars marked by an asterisk are significantly different from each other (MWT: $Z=2.36, N=16, p=$ $0.02)$; in others cases, there is no difference between the species. 
A

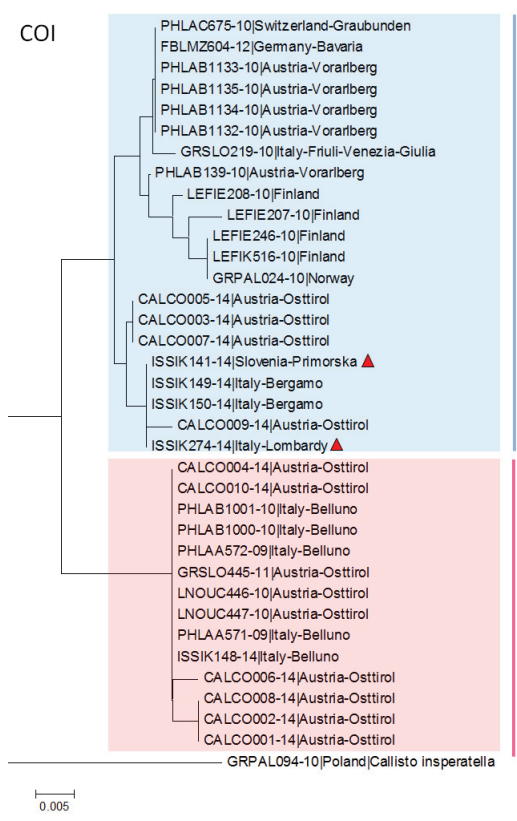

B

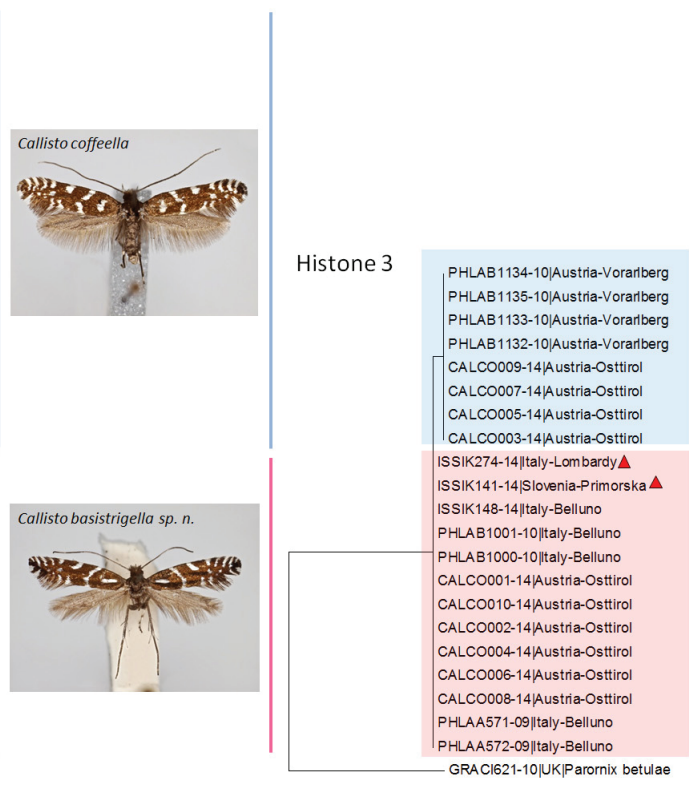

$\stackrel{101}{0.01}$

Figure 2I. A neighbor joining tree based on the COI barcode fragment and $\mathbf{B}$ based on the histone $\mathrm{H} 3$ gene. The two specimens (ISSIK141-14, ISSIK274-14) with the C. basistrigella phenotype, but branching within the C. coffeella DNA barcode and within the $C$. basistrigella histone $\mathrm{H} 3$ cluster are marked with red triangles (as in Fig. 19) in both trees.

Table I. Diagnostic substitutions in COI-DNA barcode sequences of Callisto coffeella and C. basistrigella.

\begin{tabular}{l|c|c|c|c|c|c|c|c}
\hline Position & $\mathbf{7 0}$ & $\mathbf{8 8}$ & $\mathbf{1 4 5}$ & $\mathbf{2 0 6}$ & $\mathbf{2 7 1}$ & $\mathbf{2 9 5}$ & $\mathbf{5 4 7}$ & $\mathbf{6 3 1}$ \\
\hline C. basistrigella & $\mathrm{T}$ & $\mathrm{T}$ & $\mathrm{T}$ & $\mathrm{C}$ & $\mathrm{T}$ & $\mathrm{A}$ & $\mathrm{A}$ & $\mathrm{A}$ \\
\hline C. coffeella & $\mathrm{A}$ & $\mathrm{A}$ & $\mathrm{C}$ & $\mathrm{T}$ & $\mathrm{C}$ & $\mathrm{C}$ & $\mathrm{C}$ & $\mathrm{G}$ \\
\hline
\end{tabular}

(ISSIK141-14) and one Italian (ISSIK274-14) identified morphologically (and also by nuclear data, see below) as C. basistrigella grouped with C. coffeella (Fig. 21A), suggesting introgression or incomplete lineage sorting.

Excluding these two records, pairwise interspecific distances range between 1.39\% and $2.37 \%$, with a mean value of $1.75 \%(s d=0.2)$. Within C. basistrigella and C. coffeella, respectively, genetic distances range from 0 to $0.31 \%$ (mean-value $0.17 \%$, sd $=0.11$ ) and from 0 to $1.23 \%$ (mean-value $0,56 \%, s d=0.31$ ). Sequence comparison revealed eight diagnostic substitutions (Table 1).

Histone H3. We obtained sequences of the nuclear gene histone H3 (328 bp) for the same 21 moths that were barcoded. H3 showed a high conservatism, with a single diagnostic nucleotide substitution at position 151, dividing the studied specimens into two clusters matching exactly the morphology-based separation of $C$. coffeella and $C$. basistrigella (Fig. 21B). 
The Slovenian (ISSIK141-14) and Italian (ISSIK274-14) specimens, morphologically assigned to C. basistrigella and whose DNA barcodes clustered within C. coffeella (Fig. 21A), have histone $\mathrm{H} 3$ sequences identical to other C. basistrigella specimens (Fig. 21B).

Contact zone. Both Callisto basistrigella and C. coffeella were found to occur in the same localities in the Carnic Alps (Leitnertal, Eastern Tyrol, Austria) at the altitude up to $2150 \mathrm{~m}$ (Fig. 19). Out of 9 specimens collected in Leitnertal (1 C. coffeella, 1 C. basistrigella collected on 14.VII.2013, 2 C. basistrigella on 27.VII.2013, about 30 leaf mines on Salix glabra on 07.IX.2013), 4 specimens were identified based on both morphology and genetic data as $C$. coffeella and 5 specimens were identified as C. basistrigella. In addition, 7 of 9 samples (i.e. 3 specimens of C. coffeella and 4 of C. basistrigella) were reared from the same host plant - Salix glabra. Furthermore old records confirm this sympatry in the nearby Italian Carnic Alps, in the surroundings of Sappada (1 C. coffeella and 1 C. basistrigella were collected in Passo Siera, $1600 \mathrm{~m}$, 04.VII.1933; 1 C. coffeella and 4 C. basistrigella - in L. d'Olbe, $2000 \mathrm{~m}, 02$. VII.1933) (Fig. 19B). No evidence of genetic admixture was detected in the contact zone.

\section{Discussion}

Our study used newly generated mitochondrial and nuclear data in combination with morphological and morphometric data to characterize the variability of Callisto coffeella across its range. We confirmed the existence of two distinct lineages, one of which is described here as $C$. basistrigella. Its status as a distinct species is supported by morphology, nuclear DNA (histone H3 gene) and by mtDNA (COI-DNA barcodes), although shared haplotypes of the latter suggest introgression or incomplete lineage sorting.

Species delineation with DNA barcodes. In Lepidoptera, although authors generally reject the use of a threshold to delineate species, an empirical $2 \%(\mathrm{~K} 2 \mathrm{P})$ intraspecific distance value has often been proposed, pragmatically, as indicating "deep divergence" suggestive of potential overlooked or cryptic diversity (Hebert et al. 2010; Hausmann et al. 2011; Huemer et al. 2014; Rougerie et al. 2014). In the present study, we brought to the fore a case of overlooked species in which the DNA barcode divergence between the newly recognized pair of species can be as low as $1.39 \%$; this case would then have been missed if the screening of our results had been based on the strict application of a $2 \%$ threshold before triggering further investigation. Furthermore, we reported two cases of nuclear/mitochondrial discordance in samples ISSIK141-14 and ISSIK274-14 (see Fig. 21) where histone H3 sequences and morphology conflict with the assignment based on DNA barcodes. This may have been caused by genetic introgression or incomplete lineage sorting. This finding is important as it highlights the necessary caution when using DNA barcodes for the identification of this and other pairs of closely related species. Whereas most specimens are likely to be correctly identified on the basis of this genetic marker (discordance was detected in two $(5.7 \%)$ out of 35 specimens only), one should use characters of the wing pattern (or additional genetic data) to confirm identities where certain identification is needed. 
Contact zone. We found that Callisto basistrigella occurs in sympatry with C. coffeella in the Carnic Alps, Leitnertal, 2150 m (East Tyrol, Austria) and Sappada 1600$1800 \mathrm{~m}$ (Italy), without evidence of admixture in this area. The two cases of nuclear/ mitochondrial discordance revealed suggests possible genetic introgression between the two species. Further sampling and the use of fast evolving markers will be needed to investigate the course of a putative contact zone as well as the extent of gene flow between the two species.

Biogeography and speciation. The distribution of $C$. basistrigella as currently known is shared by several other endemic Lepidoptera. The south-eastern Alps is considered as one of the major areas of endemism in the region (Huemer 1998). However, most of the taxa restricted to this area have been defined only by morphological characters so far and their taxonomy has to be re-assessed using molecular data. The specific distinctness of Udea murinalis (Fischer von Röslerstamm, 1842) and the allopatric south-eastern alpine Udea carniolica Huemer \& Tarmann, 1989 (Lepidoptera, Crambidae) both separated by moderate morphological differences, was recently well supported by molecular datasets (Mally and Nuss 2011). Another alleged set of sister taxa include Dichrorampha bugnionana bugnionana (Duponchel, 1843) and the south-eastern alpine subspecies D. bugnionana dolomitana Huemer, 1993 with a significant barcode divergence (Huemer unpublished data).

Allopatric isolation during the last glacial period is probably the main process by which $C$. basistrigella and $C$. coffeella diverged. Indeed, as many other cold-adapted Lepidoptera $C$. coffeella populations may have had a wide distribution in the periglacial tundra belts during the last glacial period. With increasing temperatures during the last interglacial period, $C$. coffeella may have moved northwards while southern populations moved up in altitude in the Alps (Mutanen et al. 2012c). On the other hand, $C$. basistrigella is restricted to the south-eastern Alps and may have derived from populations having occupied distinct refugia during the last glacial period.

Our results highlight the need to carry out additional intraspecific studies looking at patterns of both morphological and genetic variability within species across their ranges, which can reveal overlooked diversity and new species (Huemer 2011, Huemer and Mutanen 2012, Mutanen et al. 2012a-c), in regions that are thought to be well studied.

\section{Acknowledgements}

We are grateful to Marko Mutanen (Oulu, Finland), Peter Lichtmannecker (Adlkofen, Germany) and Andreas Segerer (Munich, Germany) for kindly giving us an access to unpublished barcode data of Callisto; to Jurij Rekelj (Kranj, Slovenia), Jurate and Willy De Prins (London, UK), Stanislav Gomboc (Kranj, Slovenia), Melania Massaro and Paolo Pantini (Bergamo, Italy), Jürg Schmid (Illanz, Switzerland), Christian Wieser (Klagenfurt, Austria) and Josef Wimmer (Steyr, Austria) for sending specimens for DNA barcoding; Stefan Heim (Innsbruck, Austria) for photographs of the adults and genitalia; Christelle Robinet (Orléans, France) for help with mapping; Emmanuelle Magnoux and 
Beatrice Courtial (Orléans, France) for assistance in the molecular analyses; Vladimir Shishov (Krasnoyarsk, Russia) for providing valuable comments on statistics.

We acknowledge the team at the Biodiversity Institute of Ontario, University of Guelph, Ontario, Canada for their assistance in the production of DNA barcodes. Funding for DNA barcoding was partly provided by the government of Canada through Genome Canada and the Ontario Genomics Institute in support of the International Barcode of Life project, and by NSERC. Sequence analysis was enabled by a grant from the government of Canada through Genome Canada and the Ontario Genomics Institute in support of the International Barcode of Life Project. Our work was also aided by the BOLD informatics platform whose development is funded by the Ontario Ministry of Economic Development and Innovation. Peter Huemer gratefully acknowledges funding from inatura Erlebnis Naturschau (Dornbirn, Austria) and the Promotion of Educational Policies, University and Research Department of the Autonomous Province of Bolzano - South Tyrol for support of the project "Genetic biodiversity archive - DNA barcoding of Lepidoptera of the central Alpine region (South, East and North Tyrol)". Natalia Kirichenko was supported by a fellowship of LE STUDIUM ${ }^{\circ}$, France.

We thank two anonymous reviewers and the editor, Erik van Nieukerken, for their valuable comments on the manuscript.

\section{References}

Benander P (1940) Revision von Zetterstedt's lappländischen Microlepidoptera. Opuscula entomologica 5: 49-65.

Bengtsson BÅ, Johansson R (2011) Nationalnyckeln till Sveriges flora och fauna. Fjärilar: Bronsmalar-rullvingemalar. Lepidoptera: Roeslerstammiidae-Lyonetiidae. ArtDatabanken, SLU, Uppsala, $494 \mathrm{pp}$.

De Prins J, De Prins W (2014) Global Taxonomic Database of Gracillariidae (Lepidoptera). World Wide Web electronic publication http://www.gracillariidae.net

De Waard JR, Ivanova NV, Hajibabaei M, Hebert PDN (2008) Assembling DNA barcodes: analytical methods. In: Cristofre M (Ed.) Methods in Molecular Biology: Environmental Genetics. Humana Press Inc., Totowa, USA, 275-293.

Draper NR, Smith H (1998) Applied regression analysis. Wiley series in Probability and Statistics. 3rd Edition. Wiley, 736 pp. doi: 10.1002/9781118625590

Folmer O, Black M, Hoeh W, Lutz R, Vrijenhoek R (1994) DNA primers for amplification of mitochondrial cytochrome $\mathrm{c}$ oxidase subunit I from diverse metazoan invertebrates. Molecular Marine Biology and Biotechnology 3: 294-299.

Gibeaux C (1990) Annickia alpicola nov. gen., nov. sp. (Lepidoptera Tineidae Meessiinae). Entomologica gallica 2: 23-25.

Hausmann A, Haszprunar G, Hebert PDN (2011) DNA barcoding the geometrid fauna of Bavaria (Lepidoptera): Successes, surprises, and questions. PLoS ONE 6: e17134. doi: 10.1371/journal.pone.0017134 
Heath J, Emmet MA (Eds) (1985) The moths and butterflies of Great Britain and Ireland. Vol. 2 Cossidae-Heliodinidae. Harley Books, Colchester, 460 pp.

Hebert PDN, DeWaard JR, Landry JF (2010) DNA barcodes for 1/1000 of the animal kingdom. Biology letters 6: 359-362. doi: 10.1098/rsbl.2009.0848

Hollander M, Wolfe DA (1999) Nonparametric Statistical Methods. John Wiley \& Sons, New York.

Huemer P (1990) On the identity of Annickia alpicola Gibeaux, 1990 (Lepidoptera, Tineidae, Gracillariidae). Nota lepidopterologica 13: 133-136.

Huemer P (1998) Endemische Schmetterlinge der Alpen - ein Überblick (Lepidoptera). Stapfia 55: 229-256.

Huemer P (2011) Pseudo-endemism and cryptic diversity in Lepidoptera - case studies from the Alps and the Abruzzi. Journal on Protected Mountain Areas Research eco.mont 3: 11-18. doi: 10.1553/eco.mont-3-1s11

Huemer P, Karsholt O, Mutanen M (2014) DNA barcoding as a screening tool for cryptic diversity: an example from Caryocolum, with description of a new species (Lepidoptera, Gelechiidae). Zookeys 404: 91-111. doi: 10.3897/zookeys.404.7234

Huemer P, Mutanen M (2012) Taxonomy of spatially disjunct alpine Teleiopsis albifemorella s. lat. (Lepidoptera: Gelechiidae) revealed by molecular data and morphology - how many species are there? Zootaxa 3580: 1-23.

Huemer P, Tarmann G (1993) Die Schmetterlinge Österreichs (Lepidoptera). Systematisches Verzeichnis mit Verbreitungsangaben für die einzelnen Bundesländer. Veröffentlichungen des Museum Ferdinandeum, Suppl. 5, 224 pp.

Janzen DH, Hallwachs W, Blandin P, Burns JM, Cadiou J-M, Chacon I, Dapkey T, Deans A, Epstein M, Espinoza B et al. (2009) Integration of DNA barcoding into an ongoing inventory of complex tropical biodiversity. Molecular Ecology Resources 9(s1): 1-26. doi: 10.1111/j.1755-0998.2009.02628.x

Janzen DH, Hallwachs W, Harvey DJ, Darrow K, Rougerie R, Hajibabaei M, Smith MA, Bertrand C, Gamboa IC, Espinoza B et al. (2012) What happens to the traditional taxonomy when a well-known tropical saturniid moth fauna is DNA barcoded? Invertebrate Systematics 26(6): 478. doi: 10.1071/IS12038

Laštůvka A, Laštůvka Z (2006) The European Phyllonorycter species feeding on the plants of the tribe Genisteae (Fabaceae), with descriptions of twelve new species (Lepidoptera: Gracillariidae). Acta Universitatis Agriculturae et Silviculturae Mendelianae Brunensis 54(5): 65-84. doi: 10.11118/actaun200654050065

Laštůvka Z, Laštůvka A (2012) Additional data on the Phyllonorycter haasi-group with description of two new species (Lepidoptera: Gracillariidae). SHILAP Revista Lepidopterologia 40 (158): 231-239.

Laštůvka Z, Laštůvka A, Lopez-Vaamonde C (2013) A revision of the Phyllonorycter ulicicolella species group with description of a new species (Lepidoptera: Gracillariidae). SHILAP Revista Lepidopterologia 41(162): 251-265.

Lees DC, Kawahara AY, Bouteleux O, Ohshima I, Kawakita A, Rougerie R, De Prins J, LopezVaamonde C (2013) DNA barcoding reveals a largely unknown fauna of Gracillariidae leaf-mining moths in the Neotropics. Molecular Ecology Resources 14(2): 286-296. doi: $10.1111 / 1755-0998.12178$ 
Mally R, Nuss M (2011) Molecular and morphological phylogeny of European Udea moths (Insecta: Lepidoptera: Pyraloidea). Arthropod Systematics and Phylogeny 69: 55-71.

Montgomery DC (2001) Design and Analysis of Experiments. 5th ed. Wiley, New York, 696 pp. Müller-Rutz J (1920) Aus der Welt der Kleinschmetterlinge mit Beschreibungen neuer Arten und Formen. Mitteilungen der Entomologia Zürich und Umgebung 5: 334-349, pl. 2.

Mutanen M, Aarvik L, Huemer P, Kaila L, Karsholt O, Tuck K (2012a) DNA barcodes reveal that the widespread European tortricid moth Phalonidia manniana (Lepidoptera: Tortricidae) is a mixture of two species. Zootaxa 3262: 1-21.

Mutanen M, Aarvik L, Landry J-F, Segerer A, Karsholt O (2012b) Epinotia cinereana (Haworth, 1811) bona sp., a Holarctic tortricid distinct from E. nisella (Clerck, 1759) (Lepidoptera: Tortricidae: Eucosmini) as evidenced by DNA barcodes, morphology and life history. Zootaxa 3318: 1-25.

Mutanen M, Hausmann A, Hebert PDN, Landry J-F, de Waard J, Huemer P (2012c) Allopatry as a Gordian knot for taxonomists: patterns of DNA barcode divergence in arctic-alpine Lepidoptera. PLoS ONE 7: e47214. doi: 10.1371/journal.pone.0047214

Mutanen M, Kaila L, Tabell J (2013) Wide-ranging barcoding aids discovery of one-third increase of species richness in presumably well-investigated moths. Scientific Reports 3: 2901. doi: 10.1038/srep02901

Ratnasingham S, Hebert PDN (2007) BOLD: The Barcode of Life Data System (http://www.barcodinglife.org). Molecular Ecology Notes 7: 355-364. doi: 10.1111/j.1471-8286.2007.01678.x

Robinson GS (1976) The preparation of slides of Lepidoptera genitalia with special reference to the Microlepidoptera. Entomologist's Gazette 27: 127-132.

Rougerie R, Kitching IJ, Haxaire J, Miller SE, Hausmann A, Hebert PDN (2014) Australian Sphingidae - DNA barcodes challenge current species boundaries and distributions. PLoS ONE 9(7): e101108. doi: 10.1371/journal.pone.0101108

Sinev SY (2008) Catalogue of the Lepidoptera of Russia. KMK Press, St. Petersburg-Moscow, 425 pp. Svenson GJ, Whiting MF (2004) Phylogeny of Mantodea based on molecular data: evolution of a charismatic predator. Systematic Entomology 29: 359-370. doi: 10.1111/j.03076970.2004.00240.x

SwissLepTeam (2010) Die Schmetterlinge (Lepidoptera) der Schweiz. Eine kommentierte, systematisch-faunistische Liste. Fauna Helvetica 25, 349 pp.

Tamura K, Peterson D, Peterson N, Stechrer G, Nei M, Kumar S (2011) MEGA5: Molecular evolutionary genetics analysis using maximum likelihood, evolutionary distance and maximum parsimony methods. Molecular Biology and Evolution 28: 2731-2739. doi: $10.1093 / \mathrm{molbev} / \mathrm{msr} 121$

Triberti P (2007) The Phyllonorycter species from Palaearctic region feeding on Rosaceae (Lepidoptera, Gracillariidae). Bollettino del Museo Civico di Storia Naturale di Verona. Botanica Zoologia 31: 147-221.

Wocke MF (1862) Reise nach Finmarken von Dr. Staudinger und Dr. Wocke. II. Microlepidoptera. Stettiner Entomologische Zeitung 23: 30-78, 233-257.

Zeller PC (1847) Die Gracilarien. Linnaea Entomologica 2: 303-383, 585-586, pl. II.

Zeller PC (1850) Verzeichniss der von Herrn Jos. Mann beobachteten Toscanischen Microlepidoptera (Schluss). Stettiner Entomologische Zeitung 11: 195-212.

Zetterstedt JW (1839) Insecta Lapponica. Lipsiae, 1140 pp. 


\section{Supplementary material I}

List of studied specimens of Callisto coffeella and C. basistrigella and collection data Authors: Natalia Kirichenko, Peter Huemer, Helmut Deutsch, Paolo Triberti, Rodolphe Rougerie, Carlos Lopez-Vaamonde

Data type: collection data / voucher depository / genetic code.

Explanation note: The list of 135 examined specimens of Callisto coffeella and C. basistrigella sp. n., their collection data (country, locality, GPS coordinates, collection date and collector name) and depository data (museum or private collection) are provided in the supplementary table $S 1$. All specimens have been studied morphologically; the barcoded samples are supplied with sample ID, process ID, GenBank $\mathrm{COI}$ and GenBank H3 (if nuclear gene histone $\mathrm{H} 3$ was analyzed).

Copyright notice: This dataset is made available under the Open Database License (http://opendatacommons.org/licenses/odbl/1.0/). The Open Database License $(\mathrm{ODbL})$ is a license agreement intended to allow users to freely share, modify, and use this Dataset while maintaining this same freedom for others, provided that the original source and author(s) are credited. 